\title{
Increasing prevalence and high incidence of celiac disease in elderly people: A population-based study
} Anitta Vilppula1 ${ }^{1}$ Katri Kaukinen ${ }^{2,3}$, Liisa Luostarinen ${ }^{1}$, Ilkka Krekeläa ${ }^{4}$,
Heikki Patrikainen $^{4}$, Raisa Valve ${ }^{5}$, Markku Mäki ${ }^{6}$ and Pekka Collin*2,3

\begin{abstract}
Address: ${ }^{1}$ Department of Neurology, Päijät-Häme Central Hospital, Lahti, Finland, ${ }^{2}$ Department of Gastroenterology and Alimentary Tract Surgery, Tampere University Hospital, Tampere, Finland, ${ }^{3}$ Medical School, University of Tampere, Tampere, Finland, ${ }^{4}$ Department Internal Medicine, Päijät-Häme Central Hospital, Lahti, Finland, ${ }^{5}$ University of Helsinki, Department of Education and Development in Lahti, Helsinki, Finland and 'Paediatric Research Centre, University of Tampere and Tampere University Hospital, Tampere, Finland
\end{abstract}

Email: Anitta Vilppula - anitta.vilppula@phnet.fi; Katri Kaukinen - katri.kaukinen@uta.fi; Liisa Luostarinen - liisa.luostarinen@phsotey.fi; Ilkka Krekelä - ilkka.krekela@phsotey.fi; Heikki Patrikainen - heikki.patrikainen@phsotey.fi; Raisa Valve - raisa.valve@helsinki.fi; Markku Mäki - markku.maki@uta.fi; Pekka Collin* - pekka.collin@uta.fi

* Corresponding author

Published: 29 June 2009

BMC Gastroenterology 2009, 9:49 doi:10.1 186/1471-230X-9-49

This article is available from: http://www.biomedcentral.com/I47I-230X/9/49

(C) 2009 Vilppula et al; licensee BioMed Central Ltd.

This is an Open Access article distributed under the terms of the Creative Commons Attribution License (http://creativecommons.org/licenses/by/2.0), which permits unrestricted use, distribution, and reproduction in any medium, provided the original work is properly cited.
Received: 26 January 2009

Accepted: 29 June 2009

\begin{abstract}
Background: Celiac disease may emerge at any age, but little is known of its appearance in elderly people. We evaluated the prevalence of the condition in individuals over 55 years of age, and determined the incidence of biopsy-proven celiac disease (CDb) and celiac disease including seropositive subjects for anti-tissue transglutaminase antibodies $(\mathrm{CDb}+\mathrm{s})$.

Methods: The study based on prevalence figures in 2815 randomly selected subjects who had undergone a clinical examination and serologic screening for celiac disease in 2002. A second screening in the same population was carried out in 2005, comprising now 2216 individuals. Positive tissue transglutaminase antibodies were confirmed with small bowel biopsy.

Results: Within three years the prevalence of CDb increased from 2.13 to $2.34 \%$, and that of $\mathrm{CDb}+\mathrm{s}$ from 2.45 to $2.70 \%$. Five new cases were found among patients previously seronegative; two had minor abdominal symptoms and three were asymptomatic. The incidence of celiac disease in $2002-2005$ was $0.23 \%$, giving an annual incidence of $0.08 \%$ in this population.

Conclusion: The prevalence of celiac disease was high in elderly people, but the symptoms were subtle. Repeated screening detected five biopsy-proven cases in three years, indicating that the disorder may develop even in the elderly. Increased alertness to the disorder is therefore warranted.
\end{abstract}

\section{Background}

Celiac disease is a common disorder affecting more than one percent of the population in the Western world [1]. Serologic screening enables detection of individuals with atypical or subtle symptoms, or even symptomless cases [2]. The condition is often assumed to involve children and young adults. On the contrary, we recently revealed a high number of both diagnosed and undetected celiac disease among elderly people [3]. It remains obscure whether the number of undetected cases in the elderly is due to diagnostic delay, or to the development of celiac disease at an advanced age, or both. The question is important in 
contemplating whether celiac disease should be actively sought in elderly people, and whether seronegativity could exclude celiac disease once and for all. The aim of this study was to show the current prevalence and incidence of biopsy-proven celiac disease in individuals over 55 years of age. Given the high specificity of serum endomysial (EmA) and tissue transglutaminase antibodies (tTGA) for overt or forthcoming celiac disease, the frequency of seropositivity was likewise investigated.

\section{Methods}

The original study population comprised 4272 randomly selected individuals born in the years 1946-50, 1936-40 and 1926-30; the study sample was representative of the general population in the respective age groups. Altogether $2815(66 \%)$ consented to participate in the original study. Their data were collected for a 10-year research project on Ageing and well-being (Good Ageing in the Lahti region $=$ GOAL) [4]. Sera were collected in 2002, and tested for celiac disease antibodies in 2004. At that time, the number of clinically detected celiac disease cases was evaluated, and new seropositive cases underwent small intestinal biopsy for confirmation of celiac disease. The Amsterdam criteria were applied in the diagnosis of the condition [5]. In the first population screening in 2002 the frequency of diagnosed celiac disease cases was $0.89 \%$, that of screen-detected $1.24 \%$ and that of biopsyproven cases together with cases seropositive without histological confirmation of the disorder $2.45 \%$; these data have been published elsewhere [3].

In 2005, all eligible patients were asked to undergo a new serologic testing. Of the previously tested 2815 patients, 2216 consented. Again, clinically detected celiac disease cases were scrutinized. All sera were tested for IgA class tTGA; positive samples were further tested for IgA class EmA. IgA class tTGA were detected by enzyme-linked immunosorbent assay (Celikey, Phadia, Freiburg, Germany) and the limit of positivity was 5 arbitrary units; IgA class EmA were detected by an indirect immunofluorescence method using human umbilical cord as antigen; a dilution of $1: \geq 5$ was considered positive [6].

All tTGA-positive patients without previous diagnosis of celiac disease were offered upper gastrointestinal endoscopy (irrespective of the EmA titre); four small intestinal biopsies were taken form the distal part of the duodenum and stained with hematoxylin-eosin. The diagnosis of celiac disease was based on typical lesion in small intestinal mucosa.

In the prevalence estimations, subjects with previously detected celiac disease and new biopsy-proven cases found by clinically or screening were included; they are defined in this report as biopsy-proven celiac disease
$(\mathrm{CDb})$. The combined prevalence of biopsy-proven and seropositive cases included in addition individuals with positive tTGA but no histological verification of celiac disease $(\mathrm{CDb}+\mathrm{s})$.

The incidence of biopsy-proven celiac disease (CDb) was calculated in the 2216 subjects who were tested both in 2002 and 2005, and those seropositive without histological confirmation were added in the combined incidence figures $(\mathrm{CDb}+\mathrm{s})$, as defined in the prevalence figures.

\section{Screening of New Cases}

In the original on Ageing and well-being project, there were 199 individuals whose sera were not available in 2002, but consented to screening in 2005. The prevalence of $\mathrm{CDb}$ and $\mathrm{CDb}+\mathrm{s}$ in this group was estimated separately.

The study was accepted by the Ethical committee of PäijätHäme Central Hospital, and written informed consent was obtained from all participants.

\section{Statistical Analysis}

Prevalence figures were calculated with $95 \%$ confidence intervals.

\section{Results}

In the first evaluation, 61 had had been diagnosed with celiac disease (one additional case was found upon reexamination of the case records after the first publication) [3]. All 61 were alive in 2005, and were thus included in the new prevalence data.

Of the 2216 individuals proving seronegative in the first examination, six had undergone positive seroconversion and five had biopsy-proven celiac disease (Marsh III); of these five new cases two reported minor abdominal complaints and three were asymptomatic. Thus, within three years, $0.23 \%$ developed celiac disease $(\mathrm{CDb})$ and $0.24 \%$ underwent seroconversion $(\mathrm{CDb}+\mathrm{s})$. The values of IgA tTGA antibodies and EmA in the five patients with newly detected celiac disease are depicted in Table 1. The small bowel biopsy findings in patients with the lowest positive tTGA antibodies are shown in Figures 1 and 2. One of the five subjects (patient 4, Table 1) had immunosuppressive treatment (corticosteroids) upon the first and second screening. In 2005 the prevalence of celiac disease (CDb) was $2.34 \%$ in subjects aged 55 or more, and the frequency of biopsy-proven and seropositive individuals $(\mathrm{CDb}+\mathrm{s})$ 2.70\% (Table 2).

Of the 199 who underwent serologic screening for the first time in 2005, five had positive IgA tTGA antibodies and four positive EmA; three had villous atrophy compatible with celiac disease; biopsy was not possible in one who had moved away, and another subject declined due to 
Table I: Serum Tissue Transglutaminase (tTGA) and Endomysial Antibody (EmA) Levels in the Five New Cases Who Underwent Positive Seroconversion and Were Found to Have Biopsy-Proven Celiac disease.

\begin{tabular}{lllll}
\hline Gender, age (years), (by the time of diagnosis) & $\begin{array}{l}\text { Screening in 2002 } \\
\text { tTGA (Units) }\end{array}$ & EmA (titre) & $\begin{array}{l}\text { Screening in 2005 } \\
\text { tTGA (Units) }\end{array}$ \\
\hline I: Male, 67 & 0.1 & Not done & 54.6 & $1: 500$ \\
2: Female, 55 & 1.1 & Not done & 9.1 & $1: 200$ \\
3: Male, 65 & 0.8 & Not done & 9.5 & $1: 100$ \\
4: Female, 75 & 2.7 & Not done & 6.0 & $1: 5^{\mathrm{a}}$ \\
5: Male, 66 & 0 & Not done & 7.1 & 0 \\
\hline
\end{tabular}

Reference Values for $\mathrm{tTGA} \geq 5$ Units and for EmA I: $\geq 5$.

a Small bowel mucosal villous morphology is shown in Figures I and b 2

serious heart disease. Thus the frequency of celiac disease was $1.5 \%(3 / 199)$, and when seropositives were included, $2.5 \%(5 / 199)$.

\section{Discussion}

We have previously shown that the prevalence of celiac disease was higher in the elderly than what has been reported in the Finnish population among adolescents $(1.5 \%)$ [7] or adults $(2.0 \%)$ [8]. This difference might be due to diagnostic delay, which would increase the prevalence of the disease by time; the mortality of patients is low and comparable to that in the general population in Finland [9]. Nevertheless, from 2002 to 2005, the prevalence of biopsy-proven celiac disease (CDb) in this age group increased from $2.13 \%$ to $2.34 \%$, and the combined prevalence of disease and seropositivity $(\mathrm{CDb}+\mathrm{s})$ from $2.45 \%$ to $2.70 \%$. Such a combination makes sense: seropositivity for these specific antibodies in the absence of vil- lous atrophy often indicates early developing celiac disease [10], and seropositive without villous atrophy may even benefit of dietary treatment [11].

There was a significant increase in the tTGA values in the five subjects who underwent seroconversion and were subsequently found to have biopsy proven coeliac disease (Table 1). This implies that there occurred a true seroconversion, though we did not have the opportunity to test again the original sera. It was also notable that the biopsy showed unequivocal villous atrophy and crypt hyperplasia even in the two patients with the lowest positive tTGA levels, shown in Figure 1 and 2.

It is not excluded that some of the five patients had had seronegative celiac disease and became seropositive later. On the other hand, there is some evidence that elderly people with newly detected celiac disease rather become

Table 2: Prevalence and Incidence of Celiac Disease (CD) and Seropositivity for IgA Class Tissue Transglutaminase (tTGA) and Endomysial (EmA) Antibodies in Patients Aged Over 55 Years.

\begin{tabular}{|c|c|c|c|c|c|c|c|}
\hline $\begin{array}{l}\text { Year, total } \\
\text { population }\end{array}$ & Procedure & $\begin{array}{l}\text { Number } \\
\text { clinically } \\
\text { detected }\end{array}$ & $\begin{array}{l}\text { tTGA positive } \\
\text { in screening }\end{array}$ & $\begin{array}{l}\text { EmA positive in } \\
\text { screening }\end{array}$ & $\begin{array}{l}\text { Biopsy-proven } \\
\text { cases in } \\
\text { screening }\end{array}$ & $\begin{array}{l}\text { Overall } \\
\text { frequency of } \\
\text { biopsy proven } \\
\text { CD }\end{array}$ & $\begin{array}{l}\text { Patients with } \\
C D \text { and tTGA } \\
\text { seropositive } \\
\text { individuals }\end{array}$ \\
\hline 2002,2815 & Serum sampling & & & & & & \\
\hline 2004,2815 & $\begin{array}{l}\text { Recording of } \\
\text { detected } C D \text {. } \\
\text { First serologic } \\
\text { analysis }\end{array}$ & 25 & 48 & 43 & 35 & 60 & $69 a$ \\
\hline 2005,2216 & $\begin{array}{l}\text { Recording of } \\
\text { detected CD. } \\
\text { Second } \\
\text { serologic } \\
\text { screening }\end{array}$ & 1 & 6 & 4 & $5^{b}$ & 6 & 7 \\
\hline $\begin{array}{l}\text { Overall } \\
\text { prevalence, } \mathrm{N}= \\
2815\end{array}$ & & $0.92 \%(26 / 28 \mid 5)$ & $\begin{array}{l}1.92 \% \\
(54 / 2815)\end{array}$ & $1.70 \%(47 / 2815)$ & $\begin{array}{l}1.42 \% \\
(40 / 2815)\end{array}$ & $\begin{array}{l}2.34 \% \\
(66 / 2815)\end{array}$ & $\begin{array}{l}2.70 \% \\
(76 / 2815)\end{array}$ \\
\hline $\begin{array}{l}95 \% \text { confidence } \\
\text { intervals }\end{array}$ & & $0.57-1.27 \%$ & $1.4 \mathrm{I}-2.43 \%$ & $1.22-2.18 \%$ & $0.98-1.86 \%$ & I.78-2.90\% & $2.10-3.30 \%$ \\
\hline
\end{tabular}

a Four seropositive were found to have celiac disease between 2002-2004

bThe incidence of celiac disease $2002-2005$ was $0.23 \%$ (5/2216) 


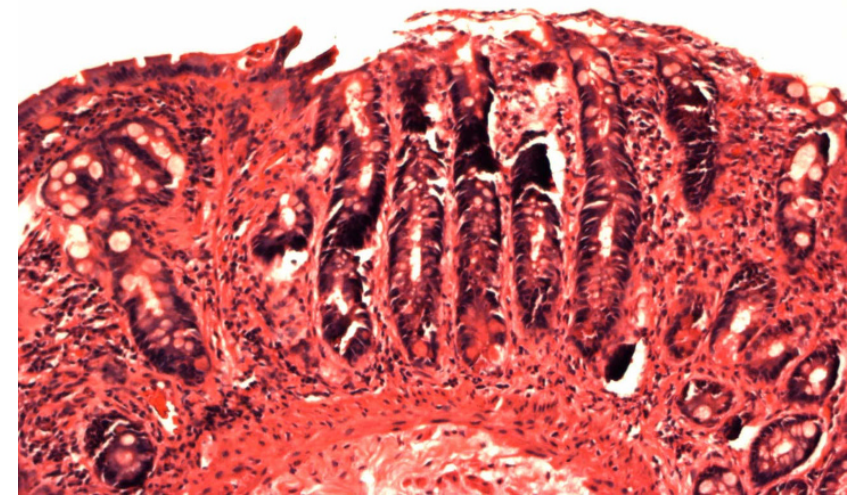

Figure I

Small-bowel biopsy sample of the patient who underwent positive seroconversion (Patient 4 in Table I).

seronegative by time [12]. This also means that the true frequency of celiac disease may be even higher than reported here.

Murray et al. [13] found that the incidence rates of celiac disease increased with age. A low index of suspicion by a physician may lead to diagnostic delay in recognition or to a distraction to other disorders. Apart from better diagnostics, a true increase in incidence may also occur [14]. We showed for the first time that the frequency of celiac disease was indeed increasing in elderly people, where clinically detected cases were recorded, and serologic screening has been carried out twice. The increase was

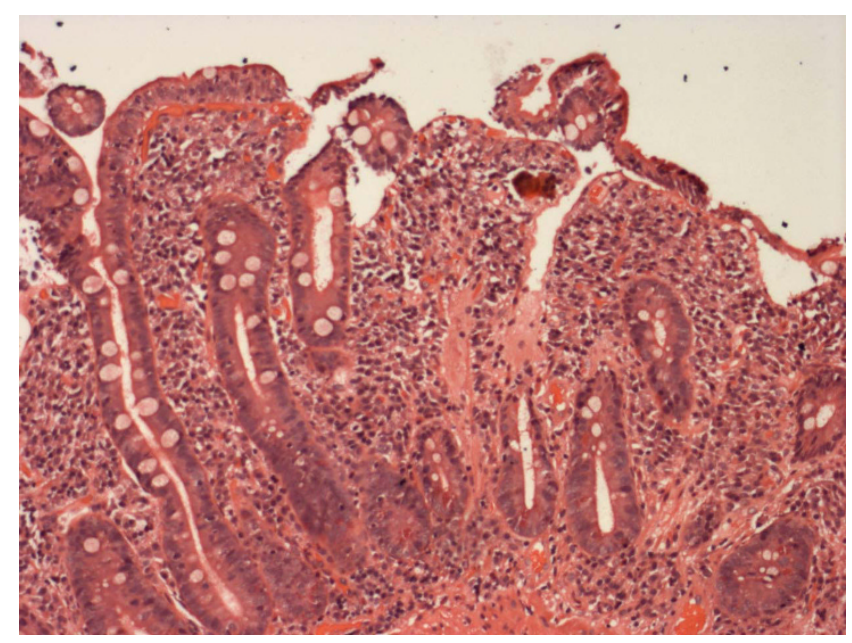

Figure 2

Small-bowel biopsy sample of the patient who underwent positive seroconversion (Patient 5 in Table I). thus not due to better diagnostics. Finland is considered genetically homogeneous, and there is no reason to believe that the frequency of celiac disease would be higher in Lahti region than in Finland in general.

The incidence of $0.23 \%$ during the study period implies that celiac disease may develop even at an advanced age. This again would imply that serologic testing should be repeated. Admittedly, the number of new cases was to low for any far-reaching conclusions. On the other hand, the annual incidence of about $0.1 \%$ indicates that the number of new cases may be $1 \%$ in 10 years. This percentage has in fact been achieved in many population screening studies. We would further emphasize that this incidence figure has been found in the general population with no suspicion of celiac disease, and with originally a high number of detected cases. The frequency of detected celiac disease in our general population is as high as $0.45 \%$ [15]. It is subject for further studies to establish whether the prevalence and incidence figures for celiac disease are even higher in elderly people belonging to the risk groups for the disease. For comparison, in relatives with celiac disease the incidence of new cases has been $1.7-4.5 \%$ within $7-12$ years [16-18].

In those 199 screened for the first time, the prevalence of biopsy-proven celiac disease (CDb) was 1.5\% (3/199), and when tTGA seroposives are included $(\mathrm{CDb}+\mathrm{s}), 2.5 \%$. These percentages are comparable to those detected in the main prospective study, supporting its results.

Earlier studies indicate that undiagnosed celiac disease may generate significant problems in the elderly. Freeman observed in his series of 30 celiac disease patients diagnosed over age 60 that they had suffered from many symptoms and had altogether 14 malignant conditions [19]. Hankey and Holmes [20] showed the diagnostic delay in the elderly to be considerable: 15 out the 35 aged 60 years or over had attended physicians for an average of 28 years with different complaints before the diagnosis. Their patients evinced good compliance with a gluten-free diet, and subsequently a significant improvement in their symptoms and signs. Similarly, Lurie et al. [21] found a significant lack in diagnosis, and a varied spectrum of manifestations in celiac patients diagnosed after the age of 60 .

\section{Conclusion}

In conclusion, the prevalence of celiac disease proved to be high in elderly people. Increased alertness and the free employment of serologic screening tests are warranted. One seronegative test result does not exclude forthcoming celiac disease. Our serial screening in the same population indicated that seropositivity and the disease may also 
appear later in life. This should be taken into account when considering celiac disease case finding and screening studies.

\section{Competing interests}

The authors declare that they have no competing interests.

\section{Authors' contributions}

AV participated in the study design, carried out the clinical studies, statistical analysis and drafted the manuscript. $\mathrm{KK}, \mathrm{MM}$ and PC participated in the original study design and planning of the protocol, in the analysis of the data, and in writing and revising the manuscript. IK and HP carried out the endoscopy examinations and participated in the clinical examination of the patients. LL participated in the study planning, study protocol and drafted the manuscript. RV collected the data and sera, and participated in the study design. All authors have read and approved the final manuscript.

\section{Acknowledgements}

This study and the Coeliac Disease Study Group were supported by the Competitive Research Funding of the Pirkanmaa Hospital District and Päijät-Häme Hospital, the Academy of Finland Research Council for Health, the Foundation for Paediatric Research, the Research Fund of Finnish Coeliac Society and the Marie Curie mobility grant (MRTNCT-2006-036032; TRACKS)

\section{References}

I. Green PH, Cellier C: Celiac disease. N Engl J Med 2007, 357:173|-1743.

2. Hopper AD, Hadjivassiliou M, Hurlstone DP, et al:: What is the role of serologic testing in celiac disease? A prospective, biopsyconfirmed study with economic analysis. Clin Gastroenterol Hepatol 2008, 6:3|4-320.

3. Vilppula A, Collin P, Mäki M, et al.: Undetected coeliac disease in the elderly. A biopsy-proven population-based study. Dig Liver Dis 2008, 40:809-8I3.

4. GOAL (Good Ageing in Lahti region; Ikihyvä) Fiinish research project on ageing and well-being [http://www.palme nia.helsinki.fi/ikihyva/InEnglish.html]

5. United European Gastroenterology: When is a coeliac a coeliac. Report of a working group of the United European Gastroenterology Week in Amsterdam 200 I. Eur J Gastroenterol Hepatol 200I, I3: | I 23-I I 28 .

6. Sulkanen $\mathrm{S}$, Halttunen T, Laurila $\mathrm{K}$, et al.: Tissue transglutaminase autoantibody enzyme-linked immunosorbent assay in detecting celiac disease. Gastroenterology 1998, I I 5: | 322-1328.

7. Mäki M, Mustalahti K, Kokkonen J, et al.: Prevalence of celiac disease among children in Finland. N Engl J Med 2003, 348:2517-2524

8. Lohi S, Mustalahti K, Kaukinen K, et al:: Increasing prevalence of coeliac disease over time. Aliment Pharmacol Ther 2007, 26:1217-I225

9. Viljamaa M, Kaukinen K, Pukkala E, et al:: Malignancies and mortality in patients with coeliac disease and dermatitis herpetiformis: 30-year population-based study. Dig Liver Dis 2006 38:374-380.

10. Salmi TT, Collin P, Jarvinen O, et al.: Immunoglobulin A autoantibodies against transglutaminase 2 in the small intestina mucosa predict forthcoming coeliac disease. Aliment Pharmacol Ther 2006, 24:54I-552.

II. Kurppa K, Collin P, Viljamaa M, et al.: Diagnosing mild enteropathy celiac disease: a randomized, controlled clinical study. Gastroenterology 2009, 136:816-823.
12. Salmi TT, Collin P, Korponay-Szabo IR, et al:: Endomysial antibodynegative coeliac disease: clinical characteristics and intestinal autoantibody deposits. Gut 2006, 55:1746-1753.

13. Murray JA, Van Dyke C, Plevak MF, et al.: Trends in the identification and clinical features of celiac disease in a North American community, 1950-200I. Clin Gastroenterol Hepatol 2003 , I: $19-27$.

14. Freeman HJ: Adult celiac disease in the elderly. World J Gastroenterol 2008, |4:69||-69|4.

15. Collin P, Huhtala H, Virta L, et al.: Diagnosis of celiac disease in clinical practise. Physician's alertness to the condition essential. I Clin Gastroenterol 2007, 4I: I52-I56.

16. Biagi $\mathrm{F}$, Campanella J, Bianchi PI, et al.: The incidence of coeliac disease in adult first-degree relatives. Dig Liver Dis 2008, 40:97-100.

17. Högberg L, Fälth-Magnusson K, Grodzinsky E, et al.: Familial prevalence of coeliac disease: a twenty-year follow-up study. Scand J Gastroenterol 2003, 38:6I-65.

18. Niveloni S, Pedreira S, Sugai E, et al.: The natural history of gluten sensitivity: report of two new celiac disease patients resulting from long-term follow-up of nonatrophic, first-degree relatives. Am J Gastroenterol 2000, 95:463-468.

19. Freeman $\mathrm{HJ}$ : Clinical spectrum of biopsy-defined celiac disease in the elderly. Can J Gastroenterol 1995, 9:42-46.

20. Hankey GL, Holmes GKT: Coeliac disease in the elderly. Gut 1994, 35:65-67.

21. Lurie Y, Landau DA, Pfeffer J, et al:: Celiac disease diagnosed in the elderly. J Clin Gastroenterol 2008, 42:59-6I.

\section{Pre-publication history}

The pre-publication history for this paper can be accessed here:

\section{http://www.biomedcentral.com/1471-230X/9/49/pre} pub
Publish with Bio Med Central and every scientist can read your work free of charge

"BioMed Central will be the most significant development for disseminating the results of biomedical research in our lifetime. "

Sir Paul Nurse, Cancer Research UK

Your research papers will be:

- available free of charge to the entire biomedical community

- peer reviewed and published immediately upon acceptance

- cited in PubMed and archived on PubMed Central

- yours - you keep the copyright
BioMedcentral 